INTERNATIONAL JOURNAL OF RESEARCHES IN BIOSCIENCES, AGRICULTURE AND TECHNOLOGY (c) VISHWASHANTI MULTIPURPOSE SOCIETY (Global Peace Multipurpose Socie ty) R. No. MH-659/13 (N) www.vmsindia.org

\title{
BIODIVERSITY OF GENUS SCENEDESMUS FROM LENTIC WATER BODY OF DHULE DISTRICT OF MAHARASHTRA
}

\author{
D. S. Jain \\ Head De pt. of Botany Gangamai Arts, Comm., and Science College Naga on Dist.-Dhule 424005 \\ jainde vendras@rediffmail.com
}

\begin{abstract}
:
While studying the biodiversity of algae from lentic water body of Dhule district, of Maharashtra. Ge ographically Sonvad Project dam is located at North latitude $21^{0} .4^{1}$ and longitude $74^{0} .50^{1}$ East. The Devbhane dam is situated at De vbhane of Taluka and Dist. Dhule. It lies at $21^{\circ}, 2^{1}$ North latitude and $74^{\circ}, 48^{1}$ East longitude. Dhule are rich in lentic water systems supporting a rich algal flora. Atte mpt have been undertaken to analyze and bring out the algal floristic of this region. The present contribution is to study the biodiversity of Scenedesmus. Author collected 11 taxa and have been described in present communication. Line drawings were made by Camera Lucida. Taxa we re identified with the help of standard monograph and recent literature. All taxa are be ing reported for the first time from this area. The present work en riches our knowledge of algal flora of this state.
\end{abstract}

Keywords: Biodiversity, Scenedesmus, Lentic, Maharash tra.

\section{Introduction}

Taxonomy of Algae from different aquatic habitats was studied extensively in India. But very few workers have paid attention on Biodervisity of Scenedesmus. in India. In pre sent study Biodiversity of Scenedesmus. was carried out in Sonvad project dam and Devbhane dam of Dhule. 11 species of Scenedesmus. was identified with help of Monographs and recent literature (Gunnar Nygaard 1972, Take to shi Hinode 1962, Shashikant 1998, Smith.G.M. 1920,Sengar et al 1985 ,Nandan,\&R.J.Pate11984a,1985a,Hazarika, A.K.andA.C.Datta.1994,Shashikant,andP.Gupta .1998,Pate1,R.J.andDanie1,J.K.1990,Philipose,M. T.1967, Shingh,Rashmi.1999, Tarar,J.L. and Seema Bodkhe.1998 Scott and Prescott.G.W. 1961, West. W and West G.S.1907, Bodas 1991). The present investigation have been undertaken to see the Biodiversity of the algal forms in Sonvad project dam. Such studies have not been conducted previously.

\section{Material and Methods}

The Sonvad project dam is situated near village Dongargaon of taluka Shindkheda of Dist. Dhule. It lies at North latitude 210.4 1 and longitude $740.50^{1}$ East. Three stations viz. SD-I, SD-II \& SD-III, Devbhane dam is lies at $21^{0} .2^{1}$ North Latitude and $74^{0} .48^{1}$ East Longitude. From this dam three stations were selected viz. DD-I, DD-II, DD-III. Monthly collections of algal samples made for two years. The algal samples were collected in Sunpet Jar about $150 \mathrm{ml}$ capacity. The algal materials preserved immediately in $4 \%$ formalin for taxonomic investigation.. Line drawing of different forms of Scenedesmus was made by camera Lucida. Identification was done with the aid of relevant monographs and recent literature. Standard monographs by Philipose, M.T.1967, and other relevant research publications identified the taxa of Scenedesmus...

SYSTEMATIC ENUMERATION OF SCENEDESMUS:

1. Scenedesmus bijugatus (Turpin) Kuetzing (P1.1, F.1)

F.T.Kue tzing, 1833, P.607

Colonies flat or slightly curved, of 2-4-8 cells arranged in a single linear series. Cells oblongellipsoid to ovoid with the ends broadly rounded. Cells $3.5-7 \mu$ broad $7-23 \mu$ long.

Habitat: Sonvad dam station, SD-II, October, 2012; SD-III, July, 2012.

Devbhane dam station, DD-II, November, 2012.

2. Scenedesmus bijugatus (Turpin) Kuetzing. V.minor (Hansgirg) G.M.Smith (P1.1, F.2) Smith, 1926, P.447

Cells $6.1 \mu$ long, $3.8 \mu$ broad, 4 celled colony $13.3 \mu$ long and $3.8 \mu$ broad.

Habitat: Devbhane dam station, DD-I, Septe mber, 2012.

3. Scenedesmus caudato-aculeolatus Chodat (P1.1, F.3)

R.Chodat, 1926, P.240, F.144

Colony four-celled with the cells loosely connected in a linear series. Cells more or less oblong with rounded poles. Terminal cells slightly curved and with a long recurved spine from each pole. Two to three short spines also present on the poles of terminal as well as inte rnal cells.

Habitat: Devbhane dam station, DD-II, November, 2012. 


\section{Scenedesmus dimorphus (Turpin) Kuetzing (P1.1, F.4) \\ F.T.Kue tzing, 1833, P.608 \\ Colonies 4-8 celled with the cells arranged in a linear or subalternating series, colony being more or less lunate and the apices of the cells be ing atte nuated. Cells $2-8 \mu$ broad, $14-35 \mu$ long. Habitat: Sonvad dam station, SD-I, June, 2012; SD-II, Dece mber, 2012.}

5. Scenedesmus dimorphus (Turpin) Kuetz. F.tortus G.M.Smith (P1.1, F.5)

G.M.Smith, 1926, P.188, P1.16, F.5-8.

Differs from the type in the central cells of the colony being at an angle to the axes of the terminal cells instead of being parallel to the $\mathrm{m}$.

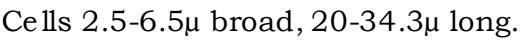

Habitat: Sonvad dam station, SD-II, July, 2012; SD-III, November, 2012.

Devbhane dam station, DD-III, May, 2012.

\section{Scenedesmus longus Meyen V.dispar} (Breb.) G.M.Smith (P1.1, F.6)

G.M.Smith, 1916, P.472, P1.27, F.4 1

Colonies four-celled. Cells oblong fusiform with acute ends and arranged in a subalternating series, usually in two planes, two cells above and two cells below. Terminal cells with spine from each pole. Cell wall usually smooth; cells

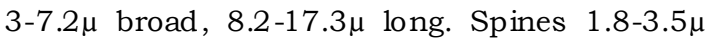
long, colony $8.2-14.2 \mu$ broad, 13.6-2 $1 \mu$ long.

Habitat: Sonvad dam station, SD-II, July, 2012; SD-III, November, 2012.

7. Scenedesmus longus Meyen. V.naegelii (Breb) G.M.Smith (P1.1, F.7)

G.M.Smith, 1920, P.156, P1.40, F.1-2 .

Colonies 2-4-8 celled. Cells more or less oblong to cylindrical to subpyriform with rounded ends, terminal cells with a long recurved spine from one pole and a long or short, straight, or sligh tly curved spine from the other pole. Cells 5.3-11 $\mu$ broad, 10.6-33 $\mu$ long.

Habitat: Sonvad dam station, SD-III, November, 2012.

Devbhane dam station, DD-II, July, 2012; DDIII, May, 2012.

8. Scenedesmus protuberans Fritsch et Rich F.minor Ley (P1.1, F.8)

S.H.Ley, 1947, P.279, F.1g

Differs from the type in having smaller cells. Terminal cells $4.4-5.3 \mu$ broad, $23-25 \mu$ long. Inner cells 4.4-5.7 $\mu$ broad, 18-22 $\mu$ long. Spines of te rminal cells $19-27 \mu$ long.
Habitat: Sonvad dam station, SD-I, July, 2012.

9. Scenedesmus quadricauda (Turpin) Breb. V.long ispina (Chodat) G.M.Smith (P1.1, F.9)

G.M.Smith, 1916, P.480, P1.27, F.42

Colonies usually 2-4 celled, rarely 8-celled. Cells ovoid to cylindrical with the cells narrower than in the type and the spines proportionately longer, compared to the length of the cells. Cells 2.5-5 $\mu$ broad, 8-15.3 $\mu$ long. Spines $7.5-15 \mu$ long. Habitat : Sonvad dam station, SD-III, Nove mber, 2012.

Devbhane dam station, DD-I, May, 2012; DD-III, May, 2012.

10. Scenedesmus quadricauda (Turpin) Breb. V.quadrispina (Chodat) G.M.Smith (P1.1, F.10)

G.M.Smith, 1916, PP.479-80, P1.27, F.43

Colonies usually $2-4$ celled. Cells broadly ovoid and about twice as long as broad. Poles of terminal cells with a single short recurved spine. Cells $3.5-8.5 \mu$ broad, 8.5-15-19 $\mu$ long. Spines 2.5-5.5 $\mu$ long.

Habitat: Sonvad dam station, SD-II, November, 2012; SD-III, December, 2012.

11. Scenedesmus quadricauda (Turpin) Breb. V.westii G.M.Smith (P1.1, F.11)

G.M.Smith, 1916, PP.480-81, P1.32, F.177-80

Colonies usually four to eight celled. Cells 4.5-9-

$13 \mu$ broad, $10-22-29 \mu$ long. Spines $10.6-16.7 \mu$ long.

Habitat : Sonvad dam station, SD-III, February, 2013.

\section{Result and Discussions}

In present study 11 species of Scenedesmus was identified from study area. (Plate-1) One species of Scenedesmus caudatoaculeolatus and one species of Scenedesmus protuberans was reported first time. Scenedesmus quadricauda was dominant in present study.

\section{Acknowledgement}

Authors are thankful to, the principal of S.S.V.P.S's L.K.P.R. Ghogrey Science College, Dhule for providing facilities. We are also thankful to Dr.P.N.Patil, The principal Gangamai Education Trust's Arts, Comm. and Science College Nagaon Dist.-Dhule for encouragement during this work. 


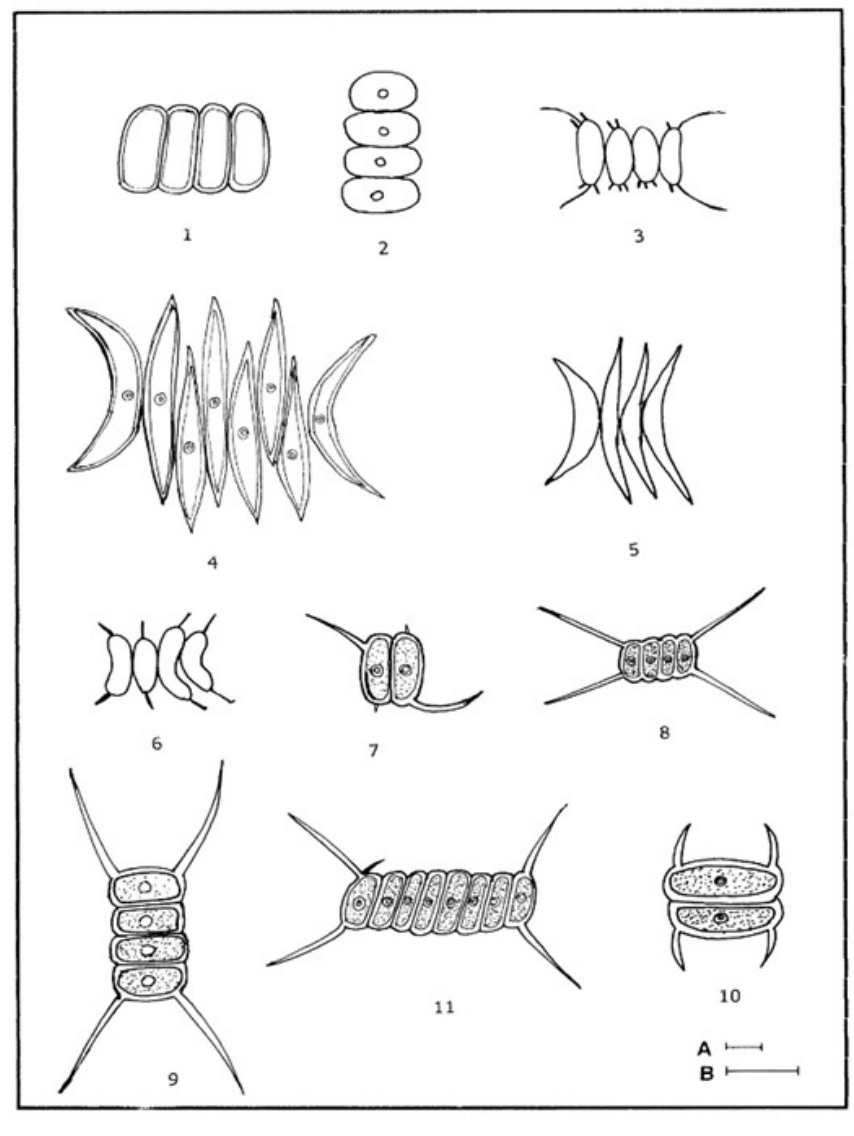

PLATE - 1

\section{References}

Bodas, K.D. (1991). Hydrobiological and taxonomical studies of lotic and lentic water in and around Nashik.Biologica Indica Delhi, pp. 686.

Gunnar Nygaard,(1972). Freshwater Phytoplankton from the Narssaq Area, South Greenland. ot.Tidsskrift bd.73, hft.3-4.

Hazarika, A.K. \& Datta, A.C. (1994). Limnological studies of two fresh water ponds of Gauwahati, Assam. Env.Eco. 12(1):26-29.

Nandan, S.N., \& Patel, R.J.(1984a).Ecological studies on algal flora of Vishwamitri River.Baroda.Gujarat India, J.P.I. Nature.2(1):17-22.

Nandan,S.N. \& Pate1, R.J.(1985a). Species diversity of algal flora in Vishwamitri River.Baroda. Gujarat. Pol.Arch. Hydrobiol. Poland. 32 (1):1-6.

Patel, R.J. \& Daniel, J.K.(1990). Some chlorococcales new to India.phykos.29:129-135.

Philipose,M.T.(1967). Chlorococcales ICAR, New Delhi. 1-356

Scott, A.M. \& Prescott,G.W.(1961). Indonesian Desmids. Hydrobiologia 17.
Sengar,R.M.S., Sharma,K.D. \&Pathak,P.D. (1985). Studieson Distribution of Algal flora in polluted and non polluted regions in Yamuna river at Agra (U .P).J.Indian Bot.Soc.64:365-376.

ShashiKank, \& Gupta. P. (1998). Algal flora of Ladakh.Scientific Pub.India,Jodhpur. pp 251258.

Shingh , Rashmi.(1999). The Systematic of Chlorophyceae of Santa

(MP).Eco.Env.andCon.5(4):357-359.

Smith,G.M.(1920).Phytoplankton of the inland lake of Wisconsin,Part-1. Exclusive of the Des mid iaceae. Wis.Geol.Nat.Hist. Surv.57:1-243.

Taketoshi Hinode. (1962). Desmids from the district, Tokushima Prefecture.Reprient from Hikobia.Vol.3,No.1 25-37, February1962.

Tarar,J.L. \& Seema Bodkhe.(1998). Studies on chlorococcales of Nagpur. Phykos. 37(1\&2):107114.

West,W.\& West,G.S. (1907). Freshwater algae of Burma, including a few form Bengal and Madras.Ann.Roy.Bot.Dard. Calcutta.6. 